- FINANSE I PRAWO FINANSOWE.

- Journal of Finance and Financial Law

Czerwiec/June 2020 • vol. 2(26): 115-128

https://doi.org/10.18778/2391-6478.2.26.08

\title{
UDZIAŁ KOSZTÓW DZIAŁALNOŚCI \\ UBEZPIECZENIOWEJ W SKŁADCE ZAKŁADÓW DZIAtU II W POLSCE
}

\author{
Anna Szymańska \\ Wydział Ekonomiczno-Socjologiczny, Uniwersytet Łódzki \\ ORCID: https://orcid.org/0000-0003-4245-7802
}

\begin{abstract}
Streszczenie
Koszty działalności ubezpieczeniowej w sprawozdawczości finansowej przedsiębiorstw ubezpieczeniowych zaliczane są do kosztów technicznych, które stanowią ponad 90\% kosztów ubezpieczycieli. Koszty te z jednej strony są jednym z czynników wpływających na wysokość składki ubezpieczeniowej, a z drugiej strony oddziaływają na wynik finansowy ubezpieczyciela. W pracy poddano analizie koszty działalności ubezpieczeniowej zakładów ubezpieczeń Działu II w latach 2009-2018. Analizę przeprowadzono na podstawie danych PIU. Wyznaczono statystyczne normy rynkowe wskaźników kosztów: działalności ubezpieczeniowej, administracyjnych oraz akwizycji. Porównano zmiany wyznaczonych norm w roku 2018 w odniesieniu do roku 2009. Oceniono obciążenie składki ubezpieczeniowej badanymi kosztami.
\end{abstract}

Słowa kluczowe: ubezpieczenia majątkowe, wskaźnik kosztów działalności ubezpieczeniowej.

JEL Class: G22, G32, G68, G38. 


\section{WSTĘP}

Kluczowym elementem działalności ubezpieczeniowej jest system taryfikacji, który jest określany mianem polityki cenowej. $Z$ jednej strony system ten decyduje o konkurencyjności zakładu ubezpieczeń na rynku, a z drugiej - determinuje wynik finansowy przedsiębiorstwa. System taryf ubezpieczeniowych jest skorelowany z ryzykiem produktu oraz kosztami działalności ubezpieczeniowej. Ubezpieczyciele, prowadząc politykę wzrostu przypisu składki, niejednokrotnie ją obniżają, akceptując niższą zyskowność operacji ubezpieczeniowych. Wszechobecne ,porównywarki” cen ubezpieczeń wymuszają na ubezpieczycielach konkurowanie poprzez cenę, a nie jakość produktu ubezpieczeniowego.

Składka ubezpieczeniowa w ubezpieczeniach majątkowych i pozostałych osobowych posiada złożoną strukturę. Jej podstawową częścią jest składka czysta, zwana także składką netto czy za ryzyko. Kalkulacja składki netto jest przeprowadzana $\mathrm{z}$ wykorzystaniem metod aktuarialnych $\mathrm{w}$ oparciu o historyczne rozkłady prawdopodobieństwa liczby i wartości odszkodowań. Składka netto powiększona o różnego rodzaju dodatki stanowi składkę brutto, która jest korygowana przez system zwyżek i zniżek, prowadząc do składki przypisanej. Wśród dodatków uwzględnianych w składce kluczową rolę pełnią koszty działalności ubezpieczeniowej. Dodatki powiększające składkę netto związane z kosztami działalności ubezpieczeniowej mogą być uwarunkowane skalą działalności poszczególnych ubezpieczycieli. Towarzystwa ubezpieczeniowe o małym przypisie składki lub krótko działające na rynku mają większy udział tych kosztów w składce. W analizie finansowej przedsiębiorstw ubezpieczeniowych miarami opisującymi, jaką część składki zakładu ubezpieczeń stanowią koszty działalności ubezpieczeniowej, są wskaźniki kosztów.

Celem badania jest ocena kosztów działalności ubezpieczeniowej w składce towarzystw ubezpieczeniowych funkcjonujących na polskim rynku ubezpieczeń majątkowych i pozostałych osobowych. W pracy zastosowano podejście badawcze oparte na danych ilościowych publikowanych przez Polską Izbę Ubezpieczeń. Dane dotyczyły całej populacji, czyli wszystkich zakładów ubezpieczeń mających zezwolenie na prowadzenie działalności ubezpieczeniowej w Dziale II w Polsce. Zakres czasowy badania obejmował lata 2009-2018. W pracy przeprowadzono analizę struktury oraz dynamiki wybranych wskaźników kosztów: działalności ubezpieczeniowej, akwizycji i administracyjnych dla zakładów ubezpieczeń Działu II w latach 2009-2018. Wyznaczono i porównano statystyczne normy rynkowe wymienionych wskaźników w roku 2009 i 2018. W pracy wykorzystano statystyczne miary analizy struktury zarówno klasyczne, jak i pozycyjne oraz miary analizy dynamiki. Postawiono hipotezę, że zakłady ubezpieczeń działające na polskim rynku w Dziale II są silnie zróżnicowane pod względem kosztów działalności ubezpieczeniowej, a zróżnicowanie to bezpośrednio wpływa na statystyczne normy wskaźników na rynku. 


\section{PRZEGLĄD LITERATURY}

Gospodarka finansowa zakładów ubezpieczeń różni się od gospodarki innych podmiotów ze względu na odwrócony cykl produkcyjny [Gąsiorkiewicz 2009: 9]. Charakteryzują go deterministyczne wpływy w postaci składek i podwójnie stochastyczne wypływy w postaci odszkodowań i świadczeń - o nieznanym momencie czasu ich powstania i ich wysokości. Ponadto, z racji tego, że ubezpieczyciele są podmiotami zaufania publicznego, zakłady ubezpieczeń obowiązują odrębne zasady rachunkowości określone w Rozporządzeniu Ministra Finansów z dnia 12 kwietnia 2016 r. w sprawie szczególnych zasad rachunkowości zakładów ubezpieczeń i zakładów reasekuracji [Dz.U. 2016, poz.562]. Szerzej specyfikę działalności zakładów ubezpieczeń pod względem regulacji prawnych i sprawozdawczości opisano m.in. w książkach [Jonas 2019; Gąsiorkiewicz 2016; Ronka-Chmielowiec (red.) 2016, Handschke i Monkiewicz (red.) 2010] oraz np. w artykułach [Czerwińska 2016: 201-204; Lament 2013: 84-122; Borda 2004: 199]. W literaturze przedmiotu nie ma przyjętego zestawu wskaźników finansowych (techniczno-ubezpieczeniowych) dla oceny sytuacji ubezpieczyciela. Podaje się różne zestawy wskaźników finansowych, często odbiegające od siebie treścią [Jonas 2016: 117; Jonczyk i in. 2006; Marcinkowska 2007]. Niestety większość wskaźników nie posiada wartości referencyjnych lub są one zbyt ogólne. W pracy Know i Wolfrom [2016: 24], dotyczącej narzędzi analitycznych dla rynku ubezpieczeniowego i nadzoru makroostrożnościowego podkreśla się, że przy obliczaniu np. wskaźnika kosztów działalności ubezpieczeniowej (underwiting expence ratio) kraje OECD stosują różne podejścia. W mianowniku wskaźnika używa się składki zarobionej brutto lub netto albo składki przypisanej brutto.

Zgodnie z metodami analizy finansowej, wartości wskaźników zakładu ubezpieczeń porównuje się z wartościami granicznymi, nazywanymi normami. Służą one nie tylko do oceny sytuacji finansowej zakładu ubezpieczeń przez zarząd i innych interesariuszy, ale mogą stanowić system wczesnego ostrzegania dla nadzoru ubezpieczeniowego. Zgodnie z metodologią systemów wczesnego ostrzegania, wartość wskaźnika w granicach „normy” jest charakterystyczna dla sprawnie funkcjonującego podmiotu lub większości zakładów ubezpieczeń w ramach jednorodnej grupy ubezpieczycieli [Bijak 2009]. Wartości „norm” wskaźników wyznacza się obiektywnie z wykorzystaniem wiedzy eksperckiej lub statystycznie, poprzez estymację odpowiednich miar pozycyjnych w podziale na działy. Biorąc pod uwagę rozwój polskiego rynku ubezpieczeniowego, zdaniem nadzoru, statystyczne podejście jest uzasadnione. Polski organ nadzoru, dawniej Państwowy Urząd Nadzoru Ubezpieczeń, w publikacjach na temat wyznaczania statystycznych granic wskaźników wyodrębnia różne kategorie wskaźników, takie jak: stymulanta, destymulanta, nominanta, nominanta stymulująca, nominanta destymulująca [PUNU 2002: 25, dostęp 3.03.2020]. Pojęcie stymulanty i destymulanty wprowadził Hellwig [1981: 48], nominanty Borys [1984: 111]. W zależności od 
kategorii wskaźnika oraz tzw. tła (dział, rodzaj kapitału własnego zakładów, forma działalności, data rozpoczęcia działalności, itd.) estymuje się granice poszczególnych wskaźników za pomocą miar pozycyjnych. W opracowaniu Know i Wolfrom [2016: 24] badania wskaźników dla krajów OECD oparto na czterostopniowej skali (0 - bardzo niski, 1 - niski, 2 - wysoki, 4 - bardzo wysoki). Metody związane z badaniem wypłacalności zakładów ubezpieczeń, audytu i nadzoru są przedstawione m.in. w pracach Bijak [2009]; Cummins i in. [1999]; BarNiv i McDoland [1992].

W monografii Chmielowiec-Lewczuk [2018] przedstawiono modelowanie strategii kosztowej w zakładach ubezpieczeń.

\section{KOSZTY DZIAŁALNOŚCI UBEZPIECZENIOWEJ}

W sprawozdawczości zakładów ubezpieczeń wyróżnia się trzy główne rodzaje kosztów: koszty techniczne, koszty działalności lokacyjnej i pozostałe koszty operacyjne [Monkiewicz 2000, t. I: 252]. Koszty działalności ubezpieczeniowej obok kosztów odszkodowań i świadczeń ujmowane są w kosztach technicznych przedsiębiorstwa.

Koszty działalności ubezpieczeniowej to suma kosztów akwizycji i kosztów administracyjnych, pomniejszona o prowizje reasekuracyjne i udziały w zyskach reasekuratorów.

Koszty akwizycji to wszystkie koszty bezpośrednie i pośrednie związane z zawieraniem umów ubezpieczenia i zainkasowaniem składki. Do kosztów bezpośrednich zalicza się prowizje pośredników ubezpieczeniowych, wynagrodzenia wraz z narzutami pracowników zajmujących się akwizycją, koszty badań lekarskich oraz ekspertyz i atestów przy ocenie ryzyka ubezpieczeniowego. Koszty pośrednie stanowią koszty reklamy i promocji produktów ubezpieczeniowych oraz koszty ogólne związane z badaniem wniosków i wystawianiem polis [Dyrektywa Rady UE z dnia 19 grudnia 1991 r..., 7-31; Rozporządzenie Ministra Finansów z dnia 28 grudnia 2009 r...]. Koszty akwizycji obejmują również płacone cedentom prowizje reasekuracyjne i udziały w zyskach.

Koszty administracyjne to koszty związane z funkcjonowaniem zarządu i administracji oraz koszty ogólne, do których zalicza się koszty utrzymania placówek biurowych, usług obcych, koszty zużycia materiałów i energii, amortyzacji środków trwałych i wartości niematerialnych i prawnych, koszty wynagrodzeń pracowników z tytułu umowy o pracę, koszty podróży służbowych oraz reklam zakładu ubezpieczeń z wyłączeniem reklam produktów.

Wartość kosztów ubezpieczeniowych ujmowanych w składce ubezpieczeniowej zależy od skali działalności zakładu oraz jakości zarządzania organizacją ubezpieczeniową. Na wysokość kosztów akwizycji wpływają również kanały dystrybucji ubezpieczeń. 


\section{KOSZTY DZIAŁALNOŚCI UBEZPIECZENIOWEJ}

W analizie finansowej wskaźniki poziomu kosztów działalności ubezpieczeniowej zalicza się do wskaźników sprawności działania [Monkiewicz i in. 2000: 235]. Pokazują one, jaką część składki przypisanej brutto zakładu ubezpieczeń stanowią poszczególne koszty.

Definicje wskaźników przedstawiono w tabeli 1.

Tabela 1. Wybrane wskaźniki kosztów

\begin{tabular}{|c|c|c|}
\hline Nazwa wskaźnika & Definicja wskaźnika & $\begin{array}{c}\text { Pożądana war- } \\
\text { tość wskaźnika }\end{array}$ \\
\hline $\begin{array}{c}\text { Wskaźnik kosztów } \\
\text { akwizycji }\end{array}$ & $\begin{array}{c}\text { (Koszty akwizycji/składka przypisana } \\
\text { brutto)100\% }\end{array}$ & $15-25 \%$ \\
\hline $\begin{array}{c}\text { Wskaźnik kosztów ad- } \\
\text { ministracyjnych }\end{array}$ & $\begin{array}{c}\text { (Koszty administracyjne/składka przypisana } \\
\text { brutto)100\% }\end{array}$ & $10-15 \%$ \\
\hline $\begin{array}{c}\text { Wskaźnik kosztów } \\
\text { działalności ubezpie- } \\
\text { czeniowej }\end{array}$ & $\begin{array}{c}\text { (Koszty działalności ubezpieczeniowej/składka } \\
\text { przypisana brutto) 100\% }\end{array}$ & do 30\% \\
\hline
\end{tabular}

Źródło: opracowanie własne na podstawie Monkiewicz i in. 2000.

Na wykresach 1-3 przedstawiono wskaźniki kosztów opisane w tabeli 1 dla Działu II w latach 2009-2018 w Polsce. Porównano wskaźniki dla danych zagregowanych oraz ich wartości przeciętne, obliczone za pomocą średniej arytmetycznej oraz mediany wskaźników zakładów.

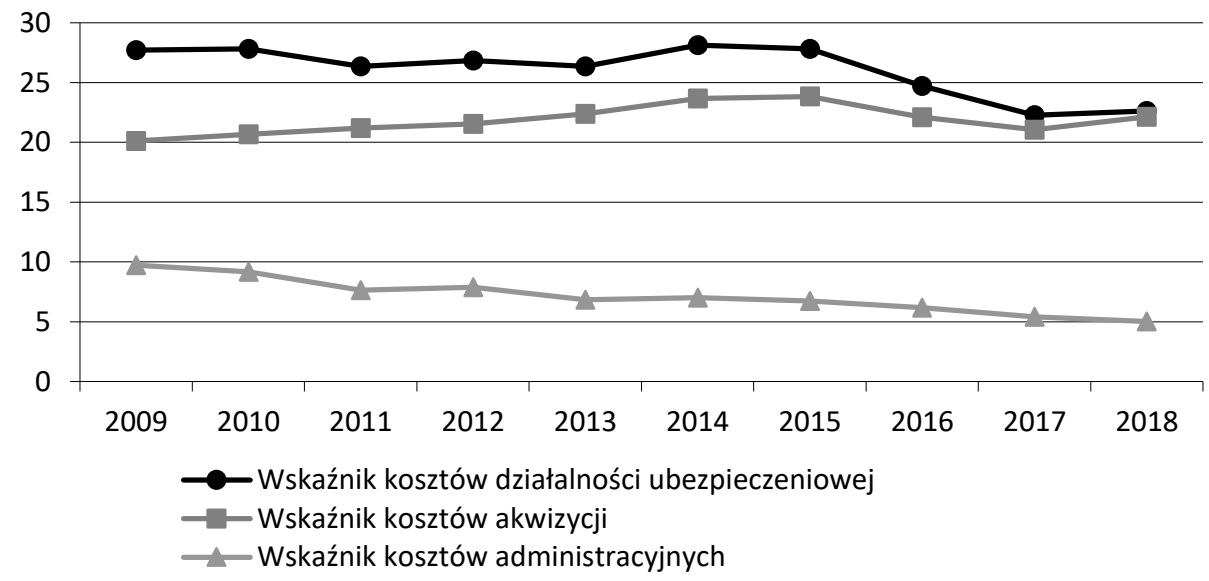

Wykres 1. Wybrane wskaźniki kosztów Działu II w Polsce w latach 2009-2018 (dane zagregowane)

Źródło: opracowanie własne na podstawie danych KNF. 


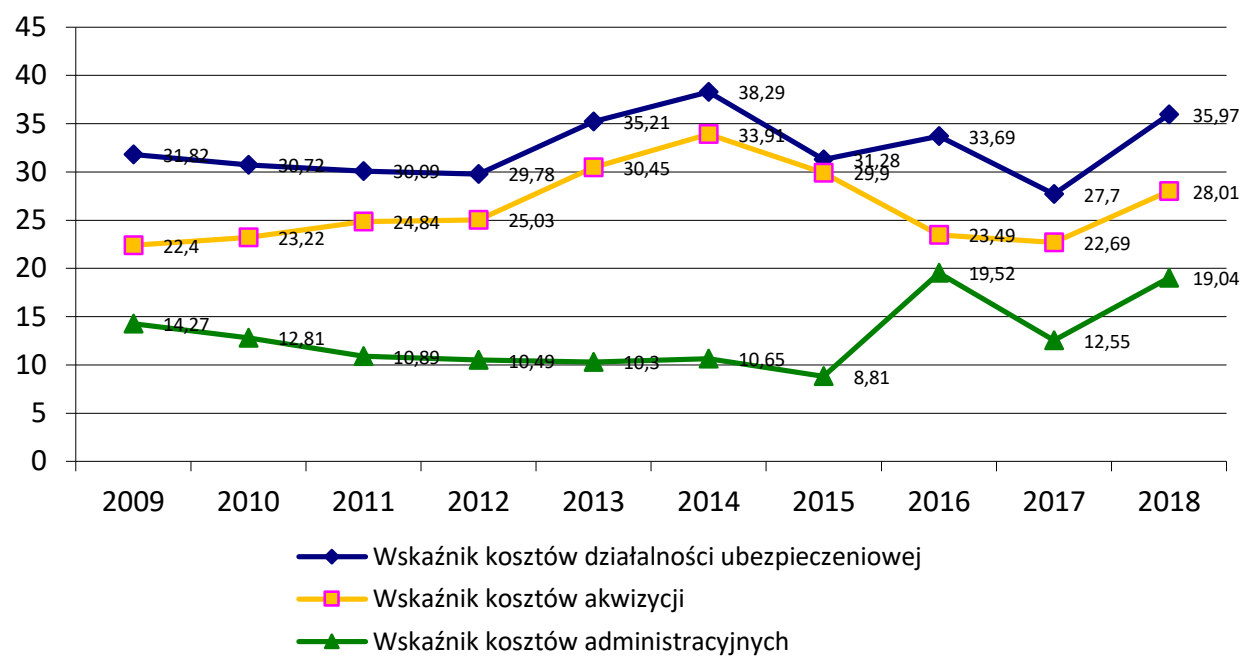

Wykres 2. Średnia wartość wskaźników kosztów działalności ubezpieczeniowej dla Działu II w Polsce w latach 2009-2018

Źródło: obliczenia własne na podstawie danych PIU.

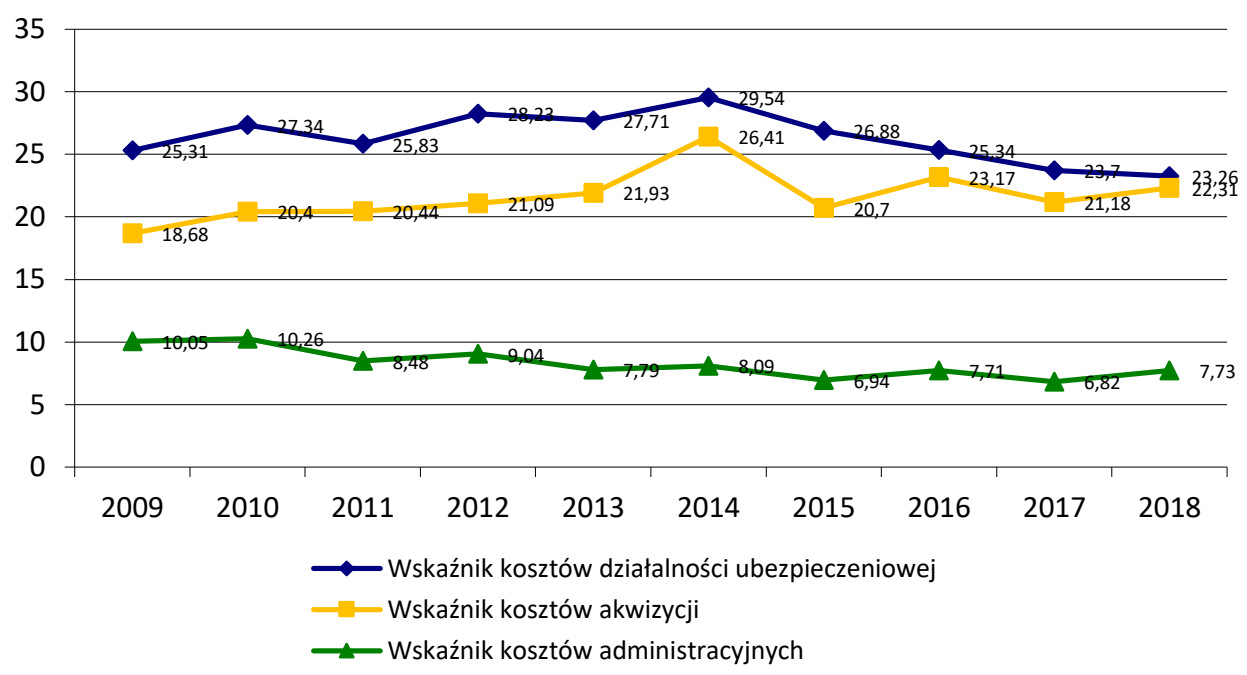

Wykres 3. Mediana wartości wskaźników kosztów działalności ubezpieczeniowej dla Działu II w Polsce w latach 2009-2018

Źródło: obliczenia własne na podstawie danych PIU. 
Zagregowany wskaźnik kosztów działalności ubezpieczeniowej w Polsce dla Działu II w latach 2009-2018 oscylował w granicach od 22,27 do 28,13\%, osiągając wartość najniższą w roku 2017, najwyższą w roku 2014. W roku 2018 wynosił 22,61\%, czyli koszty działalności ubezpieczeniowej stanowiły 22,61 zł na 100 zł składki. W badanym okresie czasu wskaźnik nie wykazywał jednokierunkowej tendencji zmian.

Zagregowany wskaźnik kosztów akwizycji wahał się od 20,12 do 23,83\%. Przy czym wzrastał z roku na rok w latach 2009-2015, a w dwóch następnych latach malał, osiągając w 2017 r. poziom 21,07\%, po czym w 2018 roku wzrósł do $22,15 \%$.

W badanych latach dla danych zagregowanych, udział kosztów administracyjnych w składce przypisanej brutto wykazywał wyraźną tendencję spadkową, zmniejszając się z 9,73\% w roku 2009 do 5,02\% w roku 2018.

Średnia wartość wskaźnika kosztów działalności ubezpieczeniowej w badanych latach wahała się od 27,7 do $38,29 \%$, czyli była o ok. 10 p.p. wyższa od granic wskaźnika dla danych zagregowanych. Jest to wynik bardzo silnego zróżnicowania tego wskaźnika dla zakładów działu. Mediana była w przedziale od 23,26 do $29,54 \%$, tylko o ok. 1 p.p. wyższa od granic dla danych zagregowanych.

Średnia wartość wskaźnika kosztów akwizycji w analizowanym okresie była w granicach od 22,4 do 33,91\% (wyższa o ok. 6 p.p. od wartości dla danych zagregowanych), mediana od 18,68 do $26,4 \%$ (wyższa o ok. 2 p.p.). Porównując analizowany wskaźnik w roku 2018 i 2009 można stwierdzić, że na polskim rynku ubezpieczeń Działu II nastąpił wzrost jego średniego poziomu o 5,61 p.p. Silniejsze było również zróżnicowanie zakładów pod względem udziału kosztów akwizycji w składce przypisanej brutto, wzrost współczynnika zróżnicowania z 58 do $81 \%$.

Średnia wartość wskaźnika kosztów administracyjnych w badanych latach wahała się od 8,81 do 19,04\% (wartości o ok. 9 p.p. większe od danych zagregowanych), mediana od 6,82 do $10,26 \%$. Porównując analizowany wskaźnik w roku 2018 i 2009 można stwierdzić, że na polskim rynku ubezpieczeń Działu II nastąpił wzrost jego średniego poziomu o 3,77 p.p. Silniejsze było również zróżnicowanie zakładów pod względem udziału kosztów administracyjnych w składce przypisanej brutto, wzrost współczynnika zróżnicowania z 99 do $198 \%$.

Według cytowanej metodologii PUNU dla omawianych wskaźników kosztów, które są destymulantami, przyjmuje się skale ocen przedstawione w tabeli 2. 
Tabela 2. Skale ocen dla destymulanty

\begin{tabular}{|c|c|}
\hline $\begin{array}{c}\text { Sytuacja zakładu ubezpieczeń/ } \\
\text { ocena poziomu wskaźnika }\end{array}$ & Wartości wskaźników \\
\hline bardzo dobra & $\leq$ percentyla 0,25 \\
\hline dobra & (percentyl 0,$25 ;$ percentyl $0,5>$ \\
\hline średnia & (percentyl 0,$5 ;$ percentyl $0,75>$ \\
\hline zła & (percentyl 0,$75 ;$ percrntyl $0,9>$ \\
\hline bardzo zła & > percentyl 0,9 \\
\hline
\end{tabular}

Źródło: opracowanie własne na podstawie PUNU [2002, dostęp 3.03.2020].

Według standardów zachodnich granicznym poziomem wskaźnika kosztów akwizycji jest 25\%, wskaźnika kosztów administracyjnych 15\% [PUNU 2002, dostęp 3.03.2020].

\section{BADANIE EMPIRYCZNE}

W części empirycznej wyznaczono granice statystyczne wybranych wskaźników kosztów w roku 2009 i 2018 dla zakładów ubezpieczeń Działu II. Granice wskaźników obliczono na podstawie danych PIU i przedstawiono na wykresach 4-6. Wyznaczone granice posłużyły do klasyfikacji zakładów ubezpieczeń według poziomu wskaźnika kosztów działalności ubezpieczeniowej w roku 2018 zamieszczonej w tabeli 3.

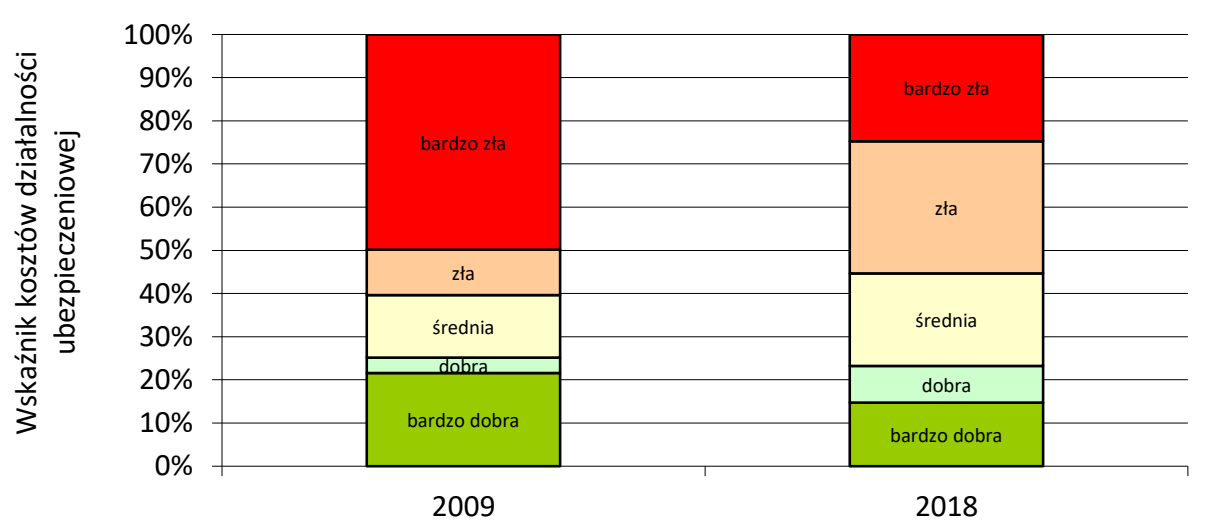

Wykres 4. Statystyczne granice wskaźnika kosztów działalności ubezpieczeniowej Działu II w Polsce w roku 2009 i 2018

Źródło: obliczenia własne na podstawie danych PIU. 
W roku 2009 statystycznie oszacowana wartość wskaźnika kosztów działalności ubezpieczeniowej wskazywała na złą i bardzo złą wartość wskaźnika dla wartości powyżej 39,65\%, w roku 2018 było to powyżej 75,29\%. Dobra lub bardzo dobra wartość wskaźnika to wartość poniżej $25,11 \%$ w 2009 r. i poniżej $23,26 \%$ w roku 2018. Wyniki wskazują, że w 2009 r. połowa zakładów miała współczynnik kosztów działalności ubezpieczeniowej nie większy niż 25,11\%, czyli dobry lub bardzo dobry. W roku 2018 połowa zakładów Działu II miała ten współczynnik mniejszy bądź równy 23,26\%. Zmniejszenie tej granicy jest zjawiskiem pozytywnym. Równocześnie w roku 2009 10\% zakładów w Polsce miała współczynnik kosztów działalności ubezpieczeniowej powyżej 50,17\%, co wskazuje na co najmniej złą relację kosztów do składki przypisanej brutto. W 2018 roku $10 \%$ zakładów miało omawiany współczynnik powyżej wartości 75,29\%. Jest to negatywne zjawisko, które wynika ze wzrostu średniego poziomu wskaźnika w roku 2018 w stosunku do roku 2009 oraz znacznego wzrostu zróżnicowania zakładów Działu II pod względem wartości wskaźnika (wzrost współczynnika zmienności z 48\% w 2009 r. do 121\% w 2018 r.).

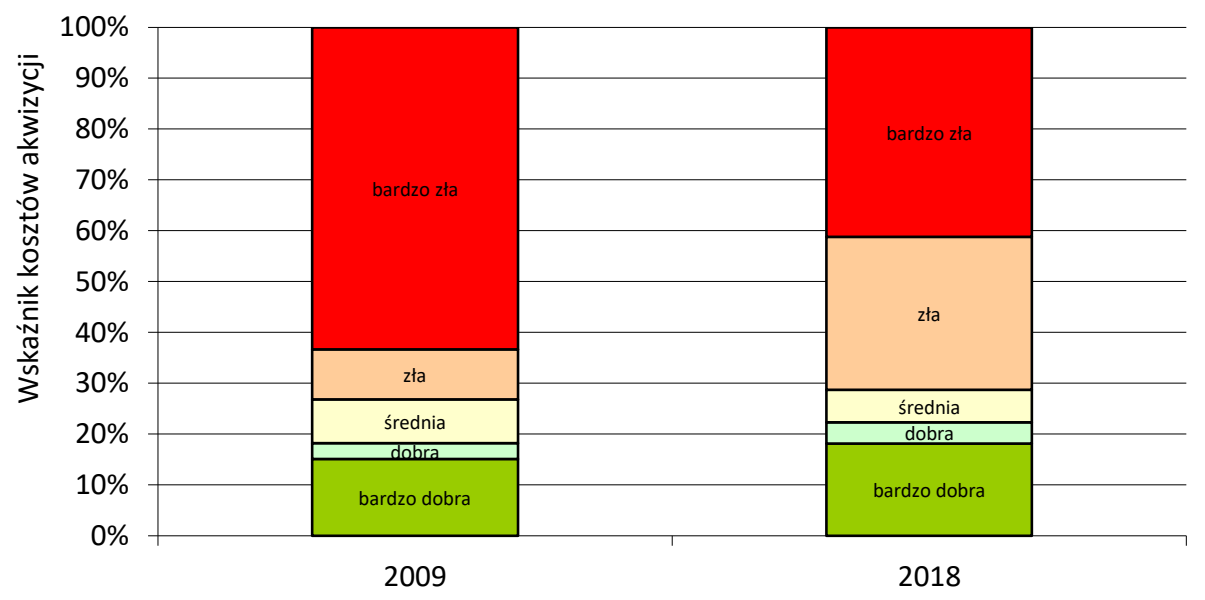

Wykres 5. Statystyczne granice wskaźnika kosztów akwizycji Działu II w Polsce w roku 2009 i 2018

Źródło: obliczenia własne na podstawie danych PIU.

W roku 2009 statystycznie oszacowane granice wskaźnika kosztów akwizycji świadczące o bardzo dobrym i dobrym poziomie wskaźnika wynosiły odpowiednio: do $15,11 \%$ i $(15,11 \% ; 18,26 \%)$. Połowa zakładów ubezpieczeń miała wskaźnik koszów akwizycji nie większy niż 18,26\%. 
W roku 2018 normy wyznaczające poziom bardzo dobry i dobry wynosiły odpowiednio: do $18,17 \%$ i $(18,7 \%$; 22,31\%). Połowa przedsiębiorstw ubezpieczeniowych miała wskaźnik kosztów akwizycji nie większy niż 22,31\%. Zatem zarówno w roku 2009, jak i w 2018 otrzymano statystyczne normy wskaźnika zgodne $\mathrm{z}$ wartościami podawanymi $\mathrm{w}$ literaturze przedmiotu jako pożądane (15\%; $25 \%)$. Również w literaturze zachodniej $25 \%$ jest granicą oddzielającą dobry i zły poziom wskaźnika. Należy jednak podkreślić wzrost tych norm dla danych krajowych, co jest skutkiem wzrostu kosztów akwizycji w 2018 roku.

W roku 2009 normy wskaźnika kosztów akwizycji wyznaczające poziom zły i bardzo zły wynosiły odpowiednio: $(26,87 \% ; 36,68 \%)$ i powyżej $36,68 \%$. Dla roku 2018 odpowiednio: $(28,75 \% ; 58,79 \%)$ i powyżej $58,79 \%$. Jest to negatywne zjawisko na polskim rynku.

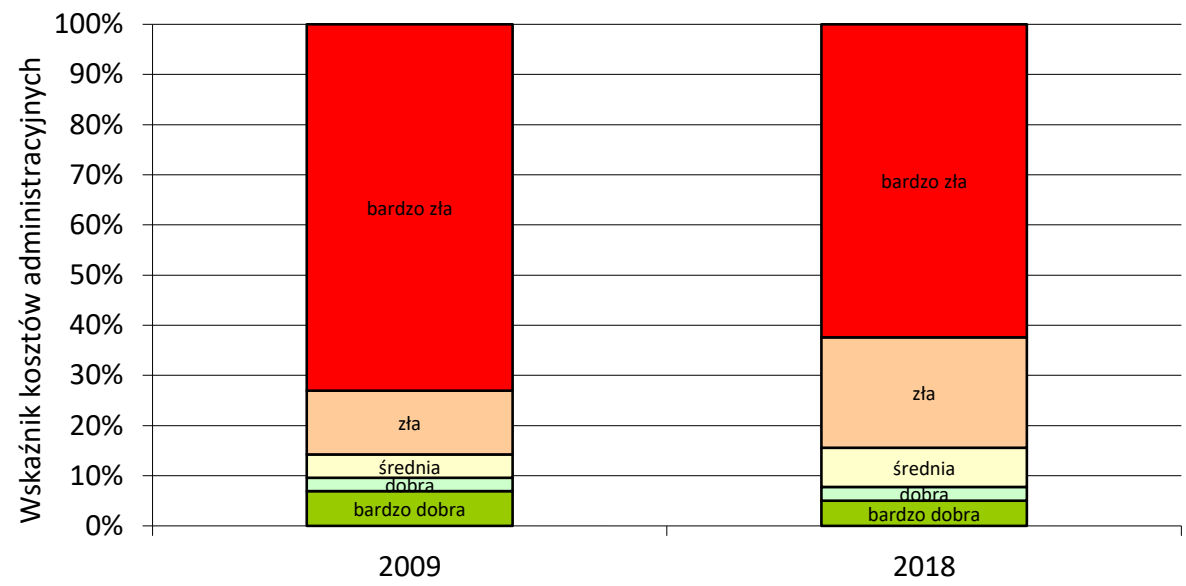

Wykres 6. Statystyczne granice wskaźnika kosztów administracyjnych Działu II w Polsce w roku 2009 i 2018

Źródło: obliczenia własne na podstawie danych PIU.

W 2009 roku wskaźnik kosztów administracyjnych nieprzekraczający poziomu $9,6 \%$ oznaczał dobry lub bardzo dobry wynik, powyżej $26,99 \%$ zły lub bardzo zły. W roku 2018 było to do 7,73\% (dobry lub bardzo dobry) i powyżej $37,59 \%$ (zły lub bardzo zły).

Podsumowaniem otrzymanych wyników jest klasyfikacja zakładów Działu II według statystycznych norm wskaźników, zamieszczona w tabeli 3. 
Tabela 3. Zakłady ubezpieczeń Działu II w Polsce według statystycznych norm wskaźników kosztów

\begin{tabular}{|c|c|c|}
\hline \multicolumn{3}{|c|}{ Klasyfikacja zakładów ubezpieczeń według wskaźnika } \\
\hline $\begin{array}{l}\text { kosztów działalności } \\
\text { ubezpieczeniowej }\end{array}$ & kosztów akwizycji & kosztów administracyjnych \\
\hline PZUW TUW & POLSKI GAZ TUW & PKO TU SA \\
\hline POLSKI GAZ TUW & CUPRUM TUW & ALLIANZ POLSKA SA \\
\hline LINK4 SA & PZUW TUW & ERGO HESTIA SA \\
\hline PKO TU SA & MEDICUM TUW & ZDROWIE SA \\
\hline TUW TUW & ZDROWIE SA & COMPENSA SA \\
\hline EULER HERMES SA & EULER HERMES SA & PZUW TUW \\
\hline CUPRUM TUW & $\begin{array}{l}\text { NATIONALE NEDERLAN- } \\
\text { DEN TU SA }\end{array}$ & WARTA SA \\
\hline ZDROWIE SA & KUKE SA & UNIQA SA \\
\hline GENERALI SA & TUW TUW & LINK4 SA \\
\hline UNIQA SA & PZU SA & PZU SA \\
\hline COMPENSA SA & POCZTOWE TUW & GENERALI SA \\
\hline INTERRISK SA & LINK4 SA & INTERRISK SA \\
\hline CONCORDIA POLSKA TUW & AXA UBEZPIECZENIA SA & PTR SA \\
\hline POCZTOWE TUW & WARTA SA & CUPRUM TUW \\
\hline GOTHAER SA & $\begin{array}{c}\text { SIGNAL IDUNA POLSKA } \\
\text { SA }\end{array}$ & TUZ TUW \\
\hline PZU SA & GENERALI SA & GOTHAER SA \\
\hline TUZ TUW & GOTHAER SA & TUW TUW \\
\hline KUKE SA & COMPENSA SA & AVIVA - OGÓLNE SA \\
\hline ERGO HESTIA SA & CONCORDIA POLSKA TUW & POLSKI GAZ TUW \\
\hline WARTA SA & INTERRISK SA & CONCORDIA POLSKA TUW \\
\hline AXA UBEZPIECZENIA SA & UNIQA SA & AXA UBEZPIECZENIA SA \\
\hline ALLIANZ POLSKA SA & PTR SA & SANTANDER AVIVA SA \\
\hline PTR SA & ERGO HESTIA SA & POCZTOWE TUW \\
\hline AVIVA - OGÓLNE SA & TUZ TUW & EULER HERMES SA \\
\hline INTER POLSKA SA & ALLIANZ POLSKA SA & SALTUS TUW \\
\hline MEDICUM TUW & PKO TU SA & INTER POLSKA SA \\
\hline $\begin{array}{c}\text { SIGNAL IDUNA POLSKA } \\
\text { SA }\end{array}$ & AVIVA - OGÓLNE SA & EUROPA SA \\
\hline $\begin{array}{l}\text { NATIONALE NEDERLAN- } \\
\text { DEN TU SA }\end{array}$ & INTER POLSKA SA & KUKE SA \\
\hline D.A.S. SA & CREDIT AGRICOLE TU SA & SIGNAL IDUNA POLSKA SA \\
\hline SANTANDER AVIVA SA & SALTUS TUW & D.A.S. SA \\
\hline CREDIT AGRICOLE TU SA & SANTANDER AVIVA SA & $\begin{array}{c}\text { NATIONALE NEDERLAN- } \\
\text { DEN TU SA }\end{array}$ \\
\hline SALTUS TUW & EUROPA SA & MEDICUM TUW \\
\hline EUROPA SA & D.A.S. SA & CREDIT AGRICOLE TU SA \\
\hline $\begin{array}{l}\text { - bardzo dobry poziom wsk } \\
\text { - dobry poziom wskaźnika } \\
\text { - średni poziom wskaźnika } \\
\text { - zły poziom wskaźnika } \\
\text { - bardzo zły poziom wskaź }\end{array}$ & & \\
\hline
\end{tabular}


W tabeli 3 pogrubioną czcionką zaznaczono, według Raportu KNF [dostęp 3.03.2020], tzw. liderów Działu II na polskim rynku ubezpieczeń, czyli ubezpieczycieli, którzy mają największy udział w rynku mierzony składką przypisaną brutto. Jak wyraźnie widać, największe zakłady ubezpieczeń nie mają badanych wskaźników kosztów, z wyjątkiem wskaźnika kosztów administracyjnych, na bardzo dobrym poziomie. Wszyscy „liderzy”, oprócz PZU, mają wskaźnik kosztów działalności ubezpieczeniowej na średnim poziomie, czyli w granicach $23-45 \%$. Według badań zamieszczonych w pracy Know iWolfrom [2016: 24] wysoki poziom wskaźnika kosztów działalności ubezpieczeniowej nie jest korzystny w skali mikroekonomicznej, czyli dla zakładów ubezpieczeń, ale jest korzystny w skali makroekonomicznej, ponieważ wskazuje na większą konkurencyjność na rynku. Według wspomnianego raportu KNF, w 2018 roku koszty działalności ubezpieczeniowej stanowiły 22,27\% wszystkich kosztów ubezpieczycieli Działu II.

\section{PODSUMOWANIE}

Aż 96\% krajów OECD monitoruje wskaźnik kosztów zakładów ubezpieczeń poprzez organy nadzorujące. Uważa się, że jest on ważnym i jednym z krytycznych wskaźników dla nadzoru makroostrożnościowego.

Przeprowadzone badanie wskazuje na zachodzące na polskim rynku ubezpieczeń Działu II zmiany wartości wskaźnika kosztów ubezpieczeniowych w badanych latach. Analiza danych pozwoliła zweryfikować pozytywnie postawioną hipotezę, że zakłady ubezpieczeń są silnie zróżnicowane pod względem kosztów działalności ubezpieczeniowej. Zróżnicowanie to wzrastało w badanych latach. Rozkład analizowanego wskaźnika w roku 2009 był bardziej skoncentrowany niż w 2018 r. Oznacza to, że w 2018 r. na rynku ubezpieczeń majątkowych były zakłady ubezpieczeń o naprawdę niskich kosztach i takie, w których koszty te były na skrajnie wysokim poziomie w porównaniu do $2009 \mathrm{r}$.

W roku 2018 połowa zakładów ubezpieczeń działu ubezpieczeń osobowych oraz majątkowych funkcjonujących na polskim rynku miała wskaźnik kosztów działalności ubezpieczeniowej na dobrym lub bardzo dobrym poziomie, czyli do ok. 23\%. Dla konsumentów oznaczało to, że koszty te stanowiły najwyżej 23 zł na $100 \mathrm{zł} \mathrm{składki.} \mathrm{Przy} \mathrm{czym} \mathrm{dla} \mathrm{1/4} \mathrm{ubezpieczycieli} \mathrm{było} \mathrm{to} \mathrm{nie} \mathrm{więcej} \mathrm{niż} 14$ zł na 100 zł składki. Przedsiębiorstwa, którym udało się bardzo obniżyć koszty działalności ubezpieczeniowej miały udział tych kosztów na poziomie nawet 5-8 zł na 100 zł składki, czego nie można było zaobserwować w roku 2009. Wówczas najniższy udział tych kosztów wynosił 13 zł na 100 zł składki, a w przypadku 1/4 zakładów było to nie więcej niż 22 zł na 100 zł składki.

Na rynku ubezpieczeń Działu II w Polsce w latach 2009-2018 występowała negatywna tendencja wzrostu statystycznych norm wskaźników kosztów, spowodowana znacznym wzrostem zróżnicowania zakładów ubezpieczeń pod względem 
wartości analizowanych wskaźników. Należy dodać, że w roku 2018 w stosunku do roku 2009 udział kosztów działalności ubezpieczeniowej w składce zmalał o 5,11 p.p., udział kosztów akwizycji wzrósł o 2,03 p.p., a udział kosztów administracyjnych zmalał o 4,71 p.p.

Statystyczne granice wskaźników wskazują również na grupę zakładów, zwłaszcza w 2018 roku, które miały omawiane koszty na bardzo wysokim poziomie, dochodzącym nawet do 80/90 zł na 100 zł składki.

\section{BIBLIOGRAFIA}

BarNiv R., McDoland J., 1992, Identifying Financial Distress in the Insurance Industry: A Synthesisof Methodological and Empirical Issues, „Journal of Risk and Insurance”, vol. 59(4).

Bijak W., 2009, Praktyczne metody badania niewypłacalności zakładów ubezpieczeń, Oficyna Wydawnicza Szkoły Głównej Handlowej, Warszawa.

Borda M., 2004, Analiza wskaźnikowa jako instrument oceny sytuacji finansowej zaktadu ubezpieczeń, [w:] W. Ronka-Chmielowiec (red.), Zarzadzanie finansami w zaktadach ubezpieczeń, Oficyna Wydawnicza Branta, Bydgoszcz-Wrocław.

Borys T., 1984, Kategoria jakości w statystycznej analizie porównawczej, „Prace Naukowe AE we Wrocławiu", nr 284.

Chmielowiec-Lewczuk M., 2018, Modelowanie strategii kosztowej w zakładzie ubezpieczeń a wspótczesne uwarunkowania rynku, Wydawnictwo Uniwersytetu Ekonomicznego we Wrocławiu, Wrocław.

Cummins J.D., Grace M., Phillips R., 1999, Regulatory Solvency Prediction In Property-liabilityInsurance: Risk-based Capital, Audit Ratios and Cash Flow Simulation, „Journal of Risk and Insurance", vol. 66.

Czerwińska T., 2016, Specyfika gospodarki finansowej zakładów ubezpieczeń, [w:] W. Ronka-Chmielowiec (red.), Ubezpieczenia, Warszawa.

Dyrektywa Rady UE z dnia 19 grudnia 1991 r. w sprawie rocznych i skonsolidowanych sprawozdań finansowych zakładów ubezpieczeń, Dz.Urz. UE L 374 z 31.12.1991.

Gąsiorkiewicz L., 2009, Finanse zaktadów ubezpieczeń majątkowych, C.H. Beck, Warszawa.

Gąsiorkiewicz L., 2016, Analiza finansowa banków i zakładów ubezpieczeń, Oficyna Wydawnicza Politechniki Warszawskiej, Warszawa.

Handschke J., Monkiewicz J., 2010, Ubezpieczenia, Poltext, Warszawa.

Hellwig Z., 1981, Wielowymiarowa analiza porównawcza i jej zastosowanie w badaniach wielocechowych obiektów gospodarczych, [w:] W. Welfe, Metody i modele ekonomiczno-matematyczne $w$ doskonaleniu zarzadzania gospodarka socjalistyczna, PWE, Warszawa.

Jonas K., 2016, Tworzenie i analiza wyniku finansowego w zaktadach ubezpieczeń, „Studia Ekonomiczne. Zeszyty Naukowe Uniwersytetu Ekonomicznego w Katowicach", nr 285.

Jonas K., 2019, Rachunkowość zaktadów ubezpieczeń i zakładów reasekuracji. Zarys problematyki, Difin, Warszawa.

Jonczyk B., Ogrodnik H., Szewieczek D., Wieczorek M., Znaniecka K., 2006, Analiza finansowa zakładu ubezpieczeń, Wydawnictwo Akademii Ekonomicznej w Katowicach, Katowice.

KNF, Biuletyn roczny. Rynek ubezpieczeń, za lata 2009-2018, https://www.knf.gov.pl [dostęp 3.03.2020.

KNF, Raport o stanie sektora ubezpieczeń po IV kwartałach 2018, https://www.knf.gov.pl/knf/pl/komponenty/img/Raport_sektor_ubezpieczen_IV_kw_2018_65498.pdf [dostęp 3.03.2020]. 
Kwon W.J., Wolfrom L., 2016, Analytical tools for the insurance market and macro-prudentialsurveillance, „OECD Journal: Financial Market Trends”, https://www.oecd.org/pensions/Analytical-tools-insurance-market-macro-prudential-surveillance.pdf [dostęp: 24.05.2020].

Lament M., 2013, Zarządzanie finansami zakładów ubezpieczeń, [w:] M. Iwanowicz-Drozdowska (red.), Ubezpieczenia, Warszawa.

Marcinkowska M., 2007, Ocena działalności instytucji finansowych, Difin, Warszawa.

Monkiewicz J. (red.), 2000, Podstawy ubezpieczeń, t.I, Poltext, Warszawa.

Monkiewicz J., Gąsiorkiewicz L., Hadyniak B., 2000, Zarządzanie finansami ubezpieczeń, Poltext, Warszawa.

PIU, Raport roczny PIU. Pozostałe ubezpieczenia osobowe oraz ubezpieczenia majatkowe, za lata 2009-2018, https://piu.org.pl [dostęp 3.03.2020].

PUNU 2002, Metodologia analizy finansowej zakładów ubezpieczeń - wersja II, http://www.kalkulator-ubezpieczeniowy.p1/metodologia_ubezpieczen_2002.pdf [dostęp 3.03.2020].

Ronka-Chmielowiec W. (red.), 2016, Ubezpieczenia, C.H. Beck, Warszawa.

Rozporządzeniu Ministra Finansów z dnia 12 kwietnia 2016 r. w sprawie szczególnych zasad rachunkowości zakładów ubezpieczeń i zakładów reasekuracji, Dz.U. 2016, poz. 562.

Rozporządzenie Ministra Finansów z dnia 28 grudnia 2009 r. w sprawie szczególnych zasad rachunkowości zakładów ubezpieczeń i zakładów reasekuracji, Dz.U. 2009, poz. 1825 z późn. zm.

\title{
THE SHARE OF THE COSTS OF INSURANCE ACTIVITY IN THE PREMIUM OF THE COMPANIES OF DIVISION II IN POLAND
}

\begin{abstract}
The costs of insurance activity in the financial reporting of insurance companies are included in technical costs, which constitute more than $90 \%$ of insurers' costs. These costs are, on the one hand, one of the factors influencing the amount of the insurance premium, and on the other hand, they strongly influence the financial result of the insurer. The paper analyzes the costs of insurance activity of Section II insurance companies in the years 2009-2018. The analysis was based on PIU data. Statistical market norms were set for cost indicators: insurance, administrative and acquisition activities. The correlation between the the share of the insurer in the market and insurance cost index was assessed.
\end{abstract}

Keywords: property insurance, insurance activity cost index. 